\title{
PENGARUH KUALITAS PRODUK DAN \\ PENETAPAN HARGA PAKAIAN BATIK TERHADAP MINAT BELI PELANGGAN PASAR TANAH ABANG
}

\author{
Hj. Nursimah Dara, Nining Purnaningsih \\ nursimahdara05@gmail.com, nining1015@gmail.com
}

Dosen Fakultas Ekonomi dan Bisnis Program Studi Manajemen

Universitas Muhammadiyah Tangerang

\begin{abstract}
The purpose of this research is to examine the effect of product quality and price on consumer buying interest in batik clothes Toko Muda Tanah Abang. The population in this research is all costumers of batik clothing of Toko Usaha Muda Tanah Abang, but the sample used with purposive sampling with customer criteria that have bought batik from Toko Usaha Muda Tanah Abang with the respondents as many as 20 customers. Technique of collecting data that is by method of questioner, interview and documentation. The variables studied include product quality and price as independent variable and buying interest as dependent variable. Data analysis using multiple linear regression. The result of analysis indicate that variable of product quality and pricing have positive and significant influence to the buying interest of Tanah Abang market.
\end{abstract}

Keywords: Product Quality, Price, Interest Buy Consumer Clothing Batik

\section{PENDAHULUAN}

Dalam era globalisasi ini persaingan bisnis di Indonesia tidak dapat terelakkan dan berkembang dengan pesat. Lebih lagi di era perdagangan bebas AFTA di tahun 2003 dan APEC pada tahun 2020 yang memberikan produsen untuk memasarkan secara bebas. Pemasar yang akan menjual produknya, berupa barang dan jasa harus mampu memenuhi apa yang dibutuhkan dan diinginkan para konsumennya, sehingga bisa memberikan nilai yang lebih baik daripada pesaingnya.

Pemasar harus mencoba mempengaruhi konsumen dengan segala cara agar konsumen bersedia membeli produk yang ditawarkannya, bahkan yang semula tidak ingin, menjadi ingin membeli. Karena pada prinsipnya konsumen yang menolak hari ini belum tentu menolak hari berikutnya, akibatnya timbul persaingan dalam menawarkan produk-produk yang berkualitas dengan harga yang mampu bersaing di pasaran. Untuk mencapai tujuan, perusahaan memerlukan berbagai usaha agar tujuan tercapai. Perusahaan-perusahaan yang tidak mampu bersaing pada akhirnya akan runtuh dengan sendirinya.

Tingkat kehidupan masyarakat yang semakin meningkat, maka kebutuhan masyarakat terhadap barang juga akan semakin meningkat. Hal ini membawa pengaruh terhadap perilaku mereka dalam memilih barang yang akan mereka beli ataupun yang mereka 
anggap paling sesuai dan benar-benar dapat memenuhi kebutuhan dan keinginan mereka. Produk yang berkualitas dengan harga bersaing merupakan kunci utama dalam memberikan nilai kepuasan yang lebih tinggi kepada konsumen.

Pada umumnya konsumen memiliki tuntutan nilai yang jauh lebih besar dan beragam karena dihadapkan pada berbagai pilihan berupa barang maupun jasa yang dapat mereka beli. Perusahaan yang cerdas akan mencoba memahami dan mencoba memenuhi apa yang mereka inginkan melalui proses pengambilan keputusan konsumen, dalam memilih, bahkan dalam menggunakan produk.

Pengambilan keputusan terdapat minat beli konsumen dalam hal kualitas harus diukur melalui sudut pandang konsumen terhadap kualitas produk itu sendiri, sehingga selera konsumen disini sangat berpengaruh. Jadi dalam mengelola kualitas suatu produk harus sesuai dengan kegunaan yang diinginkan oleh konsumen. Dalam hal ini yang penting adalah menjaga konsistensi dari output produk pada tingkat kualitas yang diinginkan dan diharapkan konsumen. Kualitas produk merupakan kemampuan suatu produk untuk melakukan fungsinya. Kemampuan suatu produk berupa ; daya tahan, kehandalan, ketelitian yang dihasilkan, kemudahan dioperasikan dan diperbaiki, serta atribut yang berharga pada produk secara keseluruhan. Semakin banyak produsen yang terlibat dalam pemenuhan kebutuhan dan keinginan konsumen, menyebabkan setiap perusahaan harus dapat teliti dalam menetapkan harga.

Harga sangat menentukan kelangsungan perusahaan, karena harga merupakan dasar laku atau tidaknya produk atau barang tersebut ketika dijual. Harga hanya dipatok dengan cara yang kompetitif, antara pebisnis atau dengan yang lainnya tidak boleh menggunakan cara-cara yang saling merugikan. Jadi kualitas dan harga adalah variabel pilihan penting bagi konsumen, sehingga harga suatu produk sangat menentukan kualitasnya.

Bisnis atau kegiatan ekonomi merupakan kegiatan di bidang usaha pemenuhan kebutuhan individu, baik berupa produksi, konsumsi maupun distribusi yang ditujukan untuk memperoleh keuntungan. Bisnis yang diperbolehkan oleh Islam adalah bisnis yang menghasilkan pendapatan yang halal dan berkah. Dunia sudah semakin terbuka dan mudah diakses atau sering disebut dengan istilah ,dunia tanpa batase $^{\text {ee }}$ dengan menghadapi resiko yang paling ditakuti yaitu persaingan antar produk, perusahaan maupun persaingan antar Negara.

Minat beli merupakan kegiatan individu yang terlibat langsung dalam mendapatkan dan menggunakan barang dan jasa, termasuk proses dalam pengambilan keputusan. Keputusan pembelian dapat dipengaruhi oleh jenis produk, harga, kualitas, merk, desain, dan waktu pembelian produk.

Keputusan pembelian juga berlaku pada bisnis batik. Masingmasing produsen batik memiliki keunggulan dan keistimewaan masingmasing, sehingga konsumen dihadapkan pada pilihan yang beragam. Persaingan dalam bisnis batik sangat kompetitif. Hal ini ditandai dengan perdagangan bebas AFTA tahun 2003 dan pemberlakuan perjanjian bebas (AFTA) ASEAN-China sejak Januari 2010 lalu dan hal ini berdampak terhadap bisnis batik local.

Berdasarkan latar belakang tersebut, maka yang menjadi pokok masalah dalam penelitian ini adalah sebagai berikut : (1) Seberapa besar pengaruh kualitas produk terhadap minat beli pelanggan Toko Usaha Muda Tanah Abang ; (2) Seberapa besar pengaruh harga terhadap minat beli pelanggan Toko Usaha Muda pasar Tanah Abang ; (3) Seberapa besar pengaruh kualitas 
produk dan harga secara simultan terhadap minat beli pelanggan Toko Usaha Muda pasar Tanah Abang?

Berdasarkan penelitian yang dilaksanakan, maka penelitian ini diharapkan dapat memberikan manfaat, sebagai berikut : Pertama. Manfaat Teoritis. Hasil Penelitian ini diharapkan memberikan kontribusi terhadap pengembangan khasanah dan wawasan ilmu pengetahuan, artinya dapat memperkuat teori-teori dari penelitian terdahulu tentang kualitas produk, penetapan harga, dan minat pembeli. Kedua. Manfaat praktis. Diharapkan dapat menjadi wawasan pengetahuan bagi penulis pada khususnya dan masyarakat pada umumnya.

\section{KAJIAN PUSTAKA}

\section{Produk}

Produk (product) menurut Kotler (2009) adalah segala sesuatu yang dapat ditawarkan kepasar untuk mendapatkan perhatian, dibeli, digunakan, atau dikonsumsi yang dapat memuaskan keinginan atau kebutuhan. Secara konseptual produk adalah pemahaman subyektif dari produsen atas sesuatu yang bisa ditawarkan sebagai usaha untuk mencapai tujuan organisasi melalui pemenuhan kebutuhan dan kegiatan konsumen, sesuai dengan kompetensi dan kapasitas organisasi serta daya beli pasar.

Menurut Kotler dan Armstrong (2008) beberapa atribut yang menyertai dan melengkapi produk (karakteristik atribut produk) adalah:

1. Merek (branding)

Merek (brand) adalah nama, istilah, tanda, simbol, atau rancangan, atau kombinasi dari semua ini yang dimaksudkan untuk mengidentifikasi produk atau jasa dari satu atau kelompok penjual dan membedakannya dari produk pesaing. Pemberian merek merupakan masalah pokok dalam strategi produk. Pemberian merek itu mahal dan memakan waktu, serta dapat membuat produk itu berhasil atau gagal. Nama merek yang baik dapat menambah keberhasilan yang besar pada produk (Kotler dan Armstrong, 2008).

2. Pengemasan (Packing)

Pengemasan (packing) adalah kegiatan merancang dan membuat wadah atau pembungkus suatu produk. Pengemasan melibatkan merancang dan membuat wadah atau pembungkus suatu produk.

3. Kualitas Produk (Product Quality) Kualitas Produk (Product Quality) adalah kemampuan suatu produk untuk melaksanakan fungsinya meliputi, daya tahan keandalan, ketepatan kemudahan operasi dan perbaikan, serta atribut bernilai lainnya. Untuk meningkatkan kualitas produk perusahaan dapat menerapkan program "Total Quality Manajemen (TQM)". Selain mengurangi kerusakan produk, tujuan pokok kualitas total adalah untuk meningkatkan nilai konsumen.

\section{Tingkatan Produk}

Menurut Kotler dan Keller (2012) terdapat lima tingkatan produk, masing-masing tingkat menambahkan lebih banyak nilai pelanggan, dan kelimanya membentuk hierarki pelanggan (customer value hierarchy). Lima tingkatan yang dimiliki oleh suatu produk yaitu:

1. Produk Utama atau Inti (Core Benefit)

2. Produk Dasar atau Produk Generik (Basic Product)

3. Produk Yang Diharapkan

4. Produk Yang Ditingkatkan (Augmented Product)

5. Produk Potential (Potential Product) 


\section{Klasifikasi Produk}

Menurut Tjiptono (2008)

klasifikasi produk bisa dilakukan atas berbagai macam sudut pandang. Berdasarkan berwujud tidaknya, produk dapat diklasifikasikan kedalam dua kelompok utama yaitu barang dan jasa. Ditinjau dari aspek daya tahannya, terdapat dua macam barang, yaitu:

1. Barang Tidak Tahan Lama (Nondurable Goods)

Barang tidak tahan lama adalah barang berwujud yang biasanya habis dikonsumsi dalam satu atau beberapa kali pemakaian. Contohnya adalah sabun, minuman dan makanan ringan, kapur tulis, gula dan garam.

2. Barang Tahan Lama (Durable Goods)

Barang tahan lama merupakan barang berwujud yang biasanya bisa bertahan lama dengan banyak pemakaian (umur ekonomisnya untuk pemakaian normal adalah satu tahun atau lebih). Contohnya antara lain TV, lemari es, mobil, dan komputer.

Produk pada umumnya diklasifikasikan berdasarkan siapa konsumennya dan untuk apa produk tersebut dikonsumsi. Berdasarkan kriteria ini, produk dapat dibedakan menjadi barang konsumen (costumer's goods) dan barang industri (industrial's goods). Barang konsumen adalah barang yang dikonsumsi untuk kepentingan konsumen akhir sendiri (individu dan rumah tangga), bukan untuk tujuan bisnis. Umumnya barang konsumen dapat diklasifikasikan menjadi empat jenis yaitu:

\section{Convinience Goods}

Convinience goods merupakan barang yang pada umumnya memiliki frekuensi pembelian tinggi (sering beli), dibutuhkan dalam waktu segera, dan hanya memerlukan usaha yang minimum (sangat kecil) dalam pembandingan dan pembeliannya. Contohnya sabun, pasta gigi, baterai, makanan, minuman, majalah, surat kabar, payung dan jas hujan.

2. Shopping Goods

Shopping goods adalah barangbarang dalam proses pemilihan dan pembeliannya dibandingkan oleh konsumen diantara berbagai alternatif yang tersedia. Kriteria perbandingan tersebut meliputi harga, kualitas dan model masingmasing barang. Contohnya alat-alat rumah tangga (TV, mesin cuci, tape recorder), furniture (mebel), dan pakaian.

3. Specially Goods

Specially goods adalah barangbarang yang memiliki karakteristik dan identifikasi merek yang unik di mana sekelompok konsumen bersedia melakukan usaha khusus untuk membelinya. Contohnya adalah barang-barang mewah dengan merek dan model spesifik.

4. Unsought Goods

Unsought goods merupakan barangbarang yang diketahui konsumen atau kalaupun sudah diketahui tetapi pada umumnya belum terpikirkan untuk membelinya. Contohnya asuransi jiwa, batu nisan, tanah kuburan (Tjiptono, 2008).

\section{Kualitas Produk}

Menurut Thamrin Abdullah dan

Francis Tantri Kualitas adalah keseluruhan ciri dan karakteristik suatu barang atau jasa yang berpengaruh pada kemampuannya untuk memuaskan kebutuhan yang dinyatakan maupun tersirat. Jelas ini adalah definisi kualitas yang berpusat pada pelanggan. Pelanggan memiliki kebutuhan dan pengharapan tertentu. Kita bias menyatakan bahwa penjual tertentu berkualitas bila produk dan pelayanannya memenuhi atau melebihi harapan pelanggan. Perusahaan yang dapat memuaskan sebagian besar 
kebutuhan pelanggan hampir sepanjang waktu adalah perusahaan berkualitas.

Menurut Kotler (2009), kualitas didefinisikan sebagai keseluruhan ciri serta sifat barang dan jasa yang berpengaruh pada kemampuan memenuhi kebutuhan yang dinyatakan maupun yang tersirat. Sedangkan menurut Tjiptono (2008), kualitas merupakan perpaduan antara sifat dan karakteristik yang menentukan sejauh mana keluaran dapat memenuhi prasyarat kebutuhan pelanggan atau menilai sampai seberapa jauh sifat dan karakteristik itu memenuhi kebutuhannya.

Menurut Kotler dan Amstrong (2008), untuk mencapai kualitas produk yang diinginkan maka diperlukan suatu standarisasi kualitas. Cara ini dimaksudkan untuk menjaga agar produk yang dihasilkan memenuhi standar yang telah ditetapkan sehingga konsumen tidak akan kehilangan kepercayaan terhadap produk yang bersangkutan. Pemasar yang tidak memperhatikan kualitas produk yang ditawarkan akan menanggung tidak loyalnya konsumen sehingga penjualan produknya pun akan cenderung menurun. Jika pemasar memperhatikan kualitas, bahkan diperkuat dengan periklanan dan harga yang wajar maka konsumen tidak akan berpikir panjang untuk melakukan pembelian terhadap produk

\section{Penetapan Harga}

Menurut Tjiptono (2002), Harga merupakan satuan moneter atau ukuran lainnya (termasuk barang dan jasa lainnya) yang, ditukarkan agar memperoleh hak kepemilikan atau penggunaan suatu barang atau jasa. Harga merupakan komponen yang berpengaruh langsung terhadap laba perusahaan. Menurut Harini (2008: 55) "Harga adalah uang (ditambah beberapa produk kalau mungkin) yang dibutuhkan untuk mendapatkan sejumlah kombinasi dari produk dan pelayanannya."

Menurut Harini (2008) Tujuan penetapan harga adalah sebagai berikut:

1. Penetapan harga untuk mencapai penghasilan atas investasi. Biasanya besar keuntungan dari suatu investasi telah ditetapkan prosentasenya dan untuk mencapainya diperlukan penetapan harga tertentu dari barang yang dihasilkannya.

2. Penetapan harga untuk kestabilan harga. Hal ini biasanya dilakukan untuk perusahaan yang kebetulan memegang kendali atas harga. Usaha pengendalian harga diarahkan terutama untuk mencegah terjadinya perang harga, khususnya bila menghadapi permintaan yang sedang menurun.

3. Penetapan harga untuk mempertahankan atau meningkatkan bagiannya dalam pasar. Apabila perusahaan mendapatkan bagian pasar dengan luas tertentu, maka ia harus berusaha mempertahankannya atau justru mengembangkannya. Untuk itu kebijaksanaan dalam penetapan harga jangan sampai merugikan usaha mempertahankan atau mengembangkan bagian pasar tersebut.

4. Penetapan harga untuk menghadapi atau mencegah persaingan. Apabila perusahaan baru mencoba-coba memasuki pasar dengan tujuan mengetahui pada harga berapa ia akan menetapkan penjualan. Ini berarti bahwa ia belum memiliki tujuan dalam menetapkan harga coba-coba tersebut.

5. Penetapan harga untuk memaksimir laba. Tujuan ini biasanya menjadi anutan setiap usaha bisnis. Kelihatannya usaha mencari untung mempunyai konotasi yang kurang enak seolah-olah menindas konsumen. Padahal sesungguhnya 
hal yang wajar saja. Setiap usaha untuk bertahan hidup memerlukan laba. Memang secara teoritis harga bisa berkembang tanpa batas.

\section{Tujuan Penetapan Harga}

Tujuan penetapan harga yang bersifat ekonomis dan non ekonomis adalah sebagai berikut

1. Memaksimalkan Laba

Penetapan harga ini biasanya memperhitungkan tingkat keuntungan yang ingin diperoleh. Semakin besar marjin keuntungan yang ingin didapat, maka menjadi tinggi pula harga yang ditetapkan untuk konsumen. Dalam menetapkan harga sebaiknya turut memperhitungkan daya beli dan variabel lain yang dipengaruhi harga agar keuntungan yang diraih dapat maksimum.

2. Meraih Pangsa Pasar

Untuk dapat menarik perhatian para konsumen yang menjadi target market atau target pasar maka suatu perusahaan sebaiknya menetapkan harga yang serendah mungkin. Dengan harga turun, maka akan memicu peningkatan permintaan yang juga datang dari market share pesaing atau kompetitor, sehingga ketika pangsa pasar tersebut diperoleh maka harga akan disesuaikan dengan tingkat laba yang diinginkan

3. Return On Investment (ROI) / Pengembalian Modal Usaha

Setiap usaha menginginkan tingkat pengembalian modal yang tinggi. ROI yang tinggi dapat dicapai dengan jalan menaikkan profit margin serta meningkatkan angka penjualan.

4. Mempertahankan Pangsa Pasar Ketika perusahaan memiliki pasar tersendiri, maka perlu adanya penetapan harga yang tepat agar dapat tetap mempertahankan pangsa pasar yang ada
5. Tujuan Stabilisasi Harga

Dalam pasar yang konsumennya sangat sensitif terhadap harga, bila suatu perusahaan menurunkan harganya, maka para pesaingnya harus menurunkan pula harga mereka. Kondisi seperti ini yang mendasari terbentuknya tujuan stabilisasi harga dalam industriindustri tertentu (misalnya minyak bumi). Tujuan stabilisasi dilakukan dengan jalan menetapkan harga untuk mempertahankan hubungan yang stabil antara harga suatu perusahaan dan harga pemimpin industri (industry leader)

6. Menjaga Kelangsungan Hidup Perusahaan

Perusahaan yang baik menetapkan harga dengan memperhitungkan segala kemungkinan agar tetap memiliki dana yang cukup untuk tetap menjalankan aktifitas usaha bisnis yang dijalani.

\section{Metode Penetapan Harga}

Secara umum tiga pendekatan metode penetapan harga adalah sebagai berikut

1. Penetapan harga berdasarkan biaya

a. Penetapan Harga Biaya Plus Didalam metode ini, harga jual per unit ditentukan dengan menghitung jumlah seluruh biaya per unit ditambah jumlah tertentu untuk menutupi laba yang dikehendaki pada unit tersebut (margin). Rumus ; Biaya Total + Margin $=$ Harga Jual

b. Penetapan Harga Mark-Up Untuk metode Mark-up ini, harga jual per unit ditentukan dengan menghitung harga pokok pembelian per unit ditambah ( mark-up ) jumlah tertentu. Rumus ; Harga Beli + Mark-Up $=$ Harga Jual

c. Penetapan Harga BEP ( Break Even Point ) 
Metode pentapan harga berdasarkan keseimbangan antara jumlah total biaya keseluruhan dengan jumlah total penerimaan keseluruhan. Rumus ; BEP $\Rightarrow$ Total Biaya $=$ Total Penerimaan

2. Penetapan Harga berdasarkan Harga Pesaing/Kompetitor

Penetapan harga dilakukan dengan menggunakan harga kompetitor sebagai referensi, dimana dalam pelaksanaannya lebih cocok untuk produk yang standar dengan kondisi pasar oligopoli. Untuk menarik dan meraih para konsumen dan para pelanggan, perusahaan biasanya menggunakan strategi harga. Penerapan strategi harga jual juga bisa digunakan untuk mensiasati para pesaingnya, misalkan dengan cara menetapkan harga di bawah harga pasar dengan maksud untuk meraih pangsa pasar.

3. Penetapan Harga Berdasarkan Permintaan

Proses penetapan harga yang didasari persepsi konsumen terhadap value/nilai yang diterima (price value), sensitivitas harga dan perceived quality. Untuk mengetahui value dari harga terhadap kualitas, maka analisa Price Sensitivity Meter (PSM) merupakan salah satu bentuk yang dapat digunakan. Pada analisa ini konsumen diminta untuk memberikan pernyataan dimana konsumen merasa harga murah, terlalu murah, terasa mahal dan terlalu mahal dan dikaitkan dengan kualitas yang diterima.

\section{Strategi Penetapan Harga}

Strategi penetapan harga adalah tahapan dimana perusahaan mengklasifikasikan dan menggolongkan produk atau jasa yang dihasilkannya merupakan 'produk baru' yang belum memiliki konsumen loyal/tetap atau produk yang telah beredar' yang telah memiliki pangsa pasar tersendiri.

Strategi penetapan harga ini juga berhubungan dengan siklus kehidupan produk (Product Life Cycle) dimana suatu produk memiliki empat tahapan utama yakni, Perkenalan, Pertumbuhan, Kematangan dan Penurunan.

Dalam menetapkan strategi penetapan harga yang efektif untuk produk baru adalah sebagai berikut

1. Harga Mengapung (Skimming Price) Memberikan harga tinggi untuk menutup biaya dan menghasilkan labamaksimum (perusahaan dapat meyakinkan konsumen bahwa produknya berbeda dengan produk sejenis yang lain.)

2. Harga Penetrasi

Memberikan harga rendah untuk menciptakan pangsa pasar dan permintaan, strategi ini dapat diterapankan pada situasi pasar tidak terfragmentasi ke dalam segmen yang berbeda, serta produk tersebut tidak mempunyai nilai simbolis yang tinggi. Pendekatan ini juga efektif terhadap sasaran pasar yang sensitif harga.

\section{Produk Yang Telah Beredar}

Selain penetapan harga baru, Strategi penetapan harga untuk produk yang telah beredar adalah sebagai berikut

1. Tahap Pertumbuhan

Pada tahap pertumbuhan ini ditandai dengan penjualan meningkat disertai munculnya pesaing. Pada awalnya terjadi pertumbuhan yang cepat, strategi yang diterapkan adalah tetap mempertahankan harga produk/pasar. Ketika pertumbuhan melambat, terapkan strategi harga agresif ; menurunkan harga untuk mendorong penjualan sekaligus menghadapi persaingan yang semakin ketat.

2. Tahap Kematangan 
Pada tahap kematangan, fleksibilitas harga merupakan kunci efektivitas strategi penetapan harga. Pada tahapan ini perusahaan harus benarbenar responsif terhadap situasi pasar, konsumen maupun pesaing. Strategi penetapan harga dapat menggunakan 'psikologis konsumen' maupun 'pemotongan harga' (diskon), sehingga perusahaan dapat menjaga loyalitas konsumen (pangsa pasar) dan meningkatkan jumlah permintaan dan keuntungan yang diperoleh.

3. Tahap Penurunan

Tahap penurunan produk atau jasa ditandai dengan menurunnya jumlah permintaan secara terus-menerus, sebagai tahap terakhir daur hidup produk terdapat dua alternatif langkah utama yang dapat dipilih. Pertama, strategi diskonting (pemotongan harga) Kedua, mempertahankan harga tetapi memotong biaya-biaya yang berhubungan dengan produk, terutama pengeluaran untuk promosi.

\section{Minat Beli}

Menurut Kotler Minat beli adalah sesuatu yang timbul setelah menerima rangsangan dari produk yang dilihatnya, dari sana timbul ketertarikan untuk membeli agar dapat memilikinya. Minat beli konsumen akan timbul dengan sendirinya jika konsumen sudah merasa tertarik atau memberikan respon yang positif terhadap apa yang ditawarkan oleh penjual.

Menurut Ali Hasan minat beli merupakan kecenderungan konsumen untuk membeli suatu merek atau mengambil tindakan guna berhubungan dengan pembelian yang diukur dengan tingkat kemungkinan konsumen melakukan pembelian. Minat beli merupakan sesuatu yang berhubungan dengan rencana konsumen untuk membeli produk tertentu serta berapa banyak unit produk yang dibutuhkan pada periode tertentu.

Minat beli merupakan pernyataan mental dari konsumen yang merefleksikan rencana pembelian sejumlah produk dengan merek tertentu. Hal ini sangat diperlukan oleh para pemasar untuk mengetahui minat beli konsumen terhadap suatu produk, baik para pemasar maupun ahli ekonomi menggunakan variabel minat untuk memprediksi perilaku konsumen di masa yang akan datang. Minat beli masa mendatang sangat dipengaruhi oleh pengalaman konsumen yang berkaitan dengan harga, merek, promosi,iklan, rantai pasokan, kombinasi (mix) layanan, suasana, dan lokasi.

Menurut Swastha (2008), Halhal yang perlu menjadi perhatian pada aspek minat beli adalah sebagai berikut

1. Minat dianggap sebagai penangkap atau perantara faktorfaktor motivasional yang memiliki dampak pada suatu perilaku.

2. Minat menunjukkan seberapa keras seseorang untuk berani mencoba atau kemauan seseorang untuk bertindak.

3. Minat menunjukkan seberapa banyak upaya yang direncanakan seseorang untuk dilakukan.

4. Minat menunjukkan hubungan terdekat dengan perilaku selanjutnya (beli atau tidak membeli).

\section{Penelitian Terdahulu}

Febby Swisstiani (Universitas Negeri Yogyakarta, 2014) dalam penelitiannya yang berjudul "Pengaruh Harga, Efektifitas Iklan Internet dan Promosi Penjualan Terhadap Minat Beli Konsumen Pada Toko Online Zalora". Hasil penelitiannya menyatakan bahwa terdapat pengaruh harga, efektifitas iklan internet dan promosi yang positif dan signifikan terhadap minatbeli 
konsumen pada Toko Online Zalora baik secara parsial maupun simultan.

Nadiah Ulfa Hanif (Universitas Islam Negeri Walisongo Semarang, 2014) dalam penelitiannya yang berjudul "Pengaruh Produk, Harga dan Promosi Terhadap Minat Beli Hijab (Studi Kasus pada Toko Fidza Collection di Desa Mayangkawis Kec. Balen Bojonegoro". Hasil penelitiannya menyatakan bahwa variabel produk, harga dan promosi berpengaruh positif dan signifikan terhadap minat beli.

Bayu Prawira dan Ni Nyoman Kerti Yasa (Universitas Udayana, Bali,Indonesia) dalam penelitian Jurnalnya yang berjudul "Pengaruh Kualitas Produk, Citra Merek dan Persepsi Harga Terhadap Minat Beli Produk Smartphone Samsung di kota Denpasar". Hasil penelitiannya menyatakan bahwa variable kualitas produk, citra merek dan persepsi harga berpengaruh positif dan signifikan terhadap minat beli.

Tika Dian Alfatris dan Mahmud dalam jurnal penelitiannya yang berjudul "Pengaruh Harga, Promosi, Kualitas Produk dan Kepercayaan (Trust) Terhadap Minat Beli K-Pop (Korean Pop) Album dengan Sistem Pre Order Secara Online (Studi pada Online Shop Kordo Day Shop (CORP) Semarang". Hasil penelitian dan hipotesis menunjukkan bahwa harga, promosi, kualitas produk dan kepercayaan berpengaruh signifikan secara parsial dan simultan terhadap minat beli.

\section{Model Konseptual Penelitian}

Dari latar belakang permasalahan dan tinjauan teoritis yang muncul, maka model konseptual adalah sebagai berikut

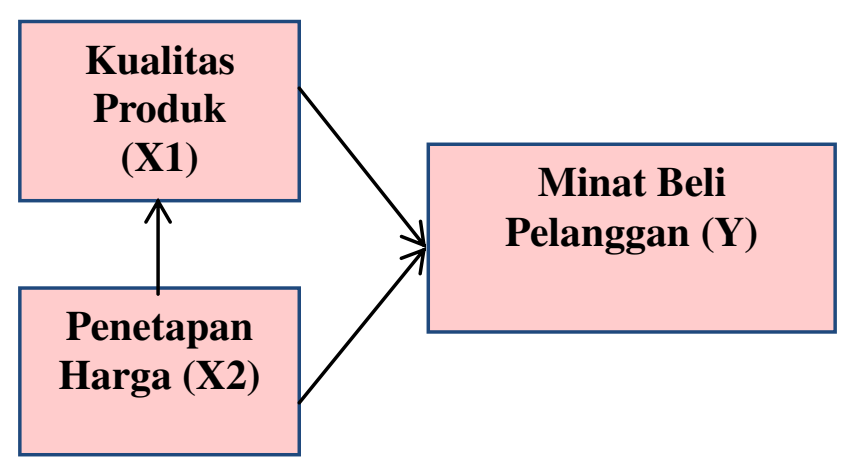

\section{Gambar 1. Model Konseptual Penelitian}

\section{METODE PENELITIAN}

\section{Tipe Penelitian}

Tipe penelitian menggunakan jenis penelitian eksplanatori, yaitu menjelaskan hubungan kausal dengan pengujian hipotesis. Penelitian ini menjelaskan pengaruh kualitas produk dan penetapan harga terhadap minat beli pelanggan batik.

\section{Populasi dan Sampel}

Penelitian hanya dilakukan unyini, peneliti menggunakan sumber data primer dan sumber data sekunder. Data Primer adalah data yang diperoleh secara langsung dari objek penetuk konsumen atau pelanggan yang membeli batik di Toko Usaha Muda.

Dalam penelitian ini teknik pengambilan sample dilakukan dengan purposive sampling dengan kriteria pelanggan yang sudah membeli batik di Toko Usaha Muda. Untuk mempermudah penelitian, maka responden dalam penelitian ini diambil sebanyak 20 pelanggan.

\section{Teknik Pengumpulan Data}

Untuk memperoleh data dan informasi yang tepat dan akurat dalam penelitian lapangan (field research) yang termasuk jenis penelitian deskriptif kuantitatif ini, peneliti melakukan 
pengumpulan data dengan cara wawancara, kuesioner dan dokumentasi.

\section{Statistic Deskritif}

Table 1. Descriptive Statistics

\begin{tabular}{|l|r|r|r|}
\hline & \multicolumn{1}{|c|}{$\mathrm{N}$} & \multicolumn{1}{c|}{ Mean } & Std. Deviation \\
\hline Kualitas Produk & 20 & 73.3500 & 8.03463 \\
Penetapan Harga & 20 & 44.0500 & 7.92381 \\
Minat Beli & 20 & 58.1000 & 3.59678 \\
Pelanggan & 20 & & \\
Valid N (listwise) & & \\
\hline
\end{tabular}

Berdasarkan hasil perhitungan, Statistic Deskritif pengujian pengaruh kualitas produk dan penetapan harga pakaian batik terhadap minat beli pelanggan pasar Tanah abang adalah sebagai berikut ; nilai rata-rata kualitas produk (X1) sebesar 73,3500 dengan standar deviasi 8,03463 dan nilai ratarata penetapan harga (X2) sebesar 44.0500dengan standar deviasi 7.92381.

\section{Uji Validitas .}

Table 2. Uji Validitas

\begin{tabular}{|c|c|c|c|c|}
\hline & & $\begin{array}{l}\text { Kualitas } \\
\text { Produk }\end{array}$ & $\begin{array}{c}\text { Penetapan } \\
\text { Harga }\end{array}$ & $\begin{array}{l}\text { Minat Beli } \\
\text { Pelanggan }\end{array}$ \\
\hline \multirow[t]{3}{*}{$\begin{array}{l}\text { Kualitas } \\
\text { Produk }\end{array}$} & $\begin{array}{l}\text { Pearson } \\
\text { Correlation }\end{array}$ & 1 & $.687^{* *}$ & $.778^{* * *}$ \\
\hline & Sig. (2-tailed) & & .001 & .000 \\
\hline & $\mathrm{N}$ & 20 & 20 & 20 \\
\hline \multirow[t]{3}{*}{$\begin{array}{l}\text { Penetapan } \\
\text { Harga }\end{array}$} & $\begin{array}{l}\text { Pearson } \\
\text { Correlation }\end{array}$ & $.687^{* *}$ & 1 & $.720^{* *}$ \\
\hline & Sig. (2-tailed) & .001 & & .000 \\
\hline & $\mathrm{N}$ & 20 & 20 & 20 \\
\hline \multirow{3}{*}{$\begin{array}{l}\text { Minat } \\
\text { Beli } \\
\text { Pelanggan }\end{array}$} & $\begin{array}{l}\text { Pearson } \\
\text { Correlation }\end{array}$ & $.778^{* *}$ & $.720^{* *}$ & 1 \\
\hline & Sig. (2-tailed) & .000 & .000 & \\
\hline & $\mathrm{N}$ & 20 & 20 & 20 \\
\hline
\end{tabular}

Berdasarkan Uji validitas menunjukkan koefsien korelasi yang lebih besar yaitu X1 sebesar 0.778 dan $\mathrm{X} 2$ sebesar 0.720 lebih besar dari $r$ table sebesar 0,687. Berarti semua pertanyaan dinyatakan valid atau dapat digunakan dan dapat dipercaya untuk mengumpulkan data yang diperlukan.

\section{Uji Reabilitas}

Table 3. Uji Reliabilitas

\begin{tabular}{|r|r|}
\hline Cronbach's Alpha & N of Items \\
\hline .829 & \\
\hline
\end{tabular}

Berdasarkan Uji reliabilitas menunjukkan koefesien Alpha sebesar 0,829 , sehingga reliable, yang berarti kuosioner yang digunakan dalam penelitian ini adalah kuosioner yang handal.

\section{Uji Normalitas}

Pengujian normalitas menggunakan uji Kolmogorov-Smirnov menunjukkan tingkat signifikansi sebesar 0,200, yang berarti menujukkan lebih besar dari angka 0,05. Maka dapat disimpukan bahwa model regresi yang digunakan memiliki distribusi data normal.

\section{Uji Normalitas}

Pengujian

normalitas menggunakan uji Kolmogorov-Smirnov menunjukkan tingkat signifikansi sebesar 0,200, yang berarti menujukkan lebih besar dari angka 0,05. Maka dapat disimpukan bahwa model regresi yang digunakan memiliki distribusi data normal.

\section{Uji Heteroskedastisitas}

Uji Heteroskedastisitas bertujuan untuk menguji apakah dalam model regresi terjadi ketidaksamaan 
varian dari residual suatu pengamatan ke pengamatan yang lain. Pengujian Heteroskedastisitas pada penelitian ini menunjukkan bahwa variable kualitas produk dan penetapan harga bebas dari Heteroskedastisitas, karena diatas 0,05

\section{Uji Autokorelasi}

Table 6. Uji Autokorelasi

\begin{tabular}{|l|r|c|}
\hline Model & R Square & $\begin{array}{c}\text { Std. Error of the } \\
\text { Estimate }\end{array}$ \\
\hline 1 & .671 & 2.18161 \\
\hline
\end{tabular}

Hasil autokorelasi menunjukkan nilai koefesien korelasi Adjusted $\mathrm{R}$ Square $=0,671$ dan Std. Error of the Estimate $=2,18161$. Maka dapat disimpulkan, bahwa pengujian penelitian tidak terjadi autokorelasi

\section{Uji signifikan $F$}

Table 8. Uji signifikan F

\begin{tabular}{|ll|c|c|}
\hline \multicolumn{2}{|l|}{ Model } & F & Sig. \\
\hline 1 & Regression \\
& Residual \\
& Total & 17.322 & $.000^{\mathrm{b}}$ \\
& & \\
\hline
\end{tabular}

Dari analisis dapat diketahui, bahwa secara bersama-sama variable independen berpengaruh yang signifikan terhadap variable dependen. Hal ini dibuktikan dari nilai $\mathrm{F}$ hitung sebesar 17,322 dengan probabilitas 0,00 , karena probabilitas lebih kecil dari tingkat signifikansi yang digunakan 5\%, maka model regresi dapat digunakan untuk memprediksi minat beli pelanggan. Hal ini menunjukkan bahwa kualitas produk dan penetapan harga secara bersamasama berpengaruh signifikan terhadap minat beli pelanggan

\section{Uji Hipotesis}

Table 9. Uji Hipotesis

\begin{tabular}{|c|c|c|c|c|c|}
\hline \multirow{2}{*}{\multicolumn{2}{|c|}{ Model }} & \multicolumn{2}{|c|}{$\begin{array}{c}\text { Unstandardized } \\
\text { Coefficients } \\
\end{array}$} & \multirow[b]{2}{*}{$\mathrm{t}$} & \multirow[b]{2}{*}{ Sig. } \\
\hline & & $\mathrm{B}$ & $\begin{array}{l}\text { Std. } \\
\text { Error }\end{array}$ & & \\
\hline \multirow[t]{3}{*}{1} & (Constant) & 33.443 & 4.621 & 7.237 & .000 \\
\hline & $\begin{array}{l}\text { Kualitas } \\
\text { Produk }\end{array}$ & .240 & .086 & 2.805 & .012 \\
\hline & $\begin{array}{l}\text { Penetapan } \\
\text { Harga }\end{array}$ & .159 & .087 & 1.835 & .084 \\
\hline
\end{tabular}

Uji $t$ adalah sarana pengujian untuk mengetahui apakah variabel independen secara individual berpengaruh terhadap variabel dependen. Minat Beli Pelanggan = $33,443+0,240+0,159$

\section{Pengaruh Kualitas Produk Terhadap Minat Beli Pelanggan}

Hasil pengujian hipotesis menunjukkan bahwa kualitas produk berpengaruh positif dan signifikan secara statistik terhadap minat beli pelanggan. Berdasarkan table hasil perhitungan uji $\mathrm{t}$ dapat dilihat nilai signifikan hitung sebesar 0,012. Karena t hitung lebih kecil angka signifikan 0,05 yang merupakan derajat kepercayaan.

\section{Pengaruh Penetapan Harga Terhadap Minat Beli Pelanggan}

Hasil pengujian hipotesis menunjukkan bahwa Penetapan Harga berpengaruh negatif dan signifikan secara statistik terhadap minat beli pelanggan. Berdasarkan table hasil perhitungan uji $\mathrm{t}$ dapat dilihat nilai signifikan hitung sebesar 0,084. Karena t hitung lebih kecil angka signifikan 0,05 yang merupakan derajat kepercayaan 


\section{PENUTUP}

Simpulan. Berdasarkan hasil pengujian hipotesis, maka diperoleh kesimpulan bahwa variable kualitas produk dan penetapan harga pakaian batik berpengaruh positif dan signifikan terhadap minat beli pelanggan Toko Usaha Muda.

Saran. Pengamatan selanjutnya dapat memperpanjang periode pengamatan dan menggunakan beberapa populasi atau bahkan secara keseluruhan di pasar Tanah Abang, sehingga lebih mewakili perhitungan secara signifikan.

\section{DAFTAR PUSTAKA}

Arikunto, Suharsimi. Prosedur Penelitian :Suatu Pendekatan Praktik, Jakarta : Rineka cipta, 2010.

Abdullah, Thamrin dan Francis Tantri. Manajemen Pemasaran, Jakarta: Rajawali Pers, 2013.

Arifin, Johan. Etika Bisnis Islami, Semarang: IAIN Press, 2008.

Azwar, Syaifudin. Metode Penelitian, Jakarta: Pustaka Pelajar, 1999.

Alfatris, Tika Dian. Jurnal Pengaruh Harga, Promosi, Kualitas Produk dan Kepercayaan (Trust) Terhadap Minat Beli

Fauzi, Mochamad .Metode Penelitian Kuantitatif, Semarang: Walisongo Press, 2009.

Frinces, Heflin. Be An Entrepreneur, Yogyakarta: Graha Ilmu, 2011.

Gitosudarmo, Indriyo.Manajemen pemasaran, Yogyakarta: BPFE, 2014. Ghozali, Imam. Aplikasi Analisis Multivariate dengan Program IBM

SPSS 22, Semarang : Universitas Diponegoro, 2012.

Hendro. Dasar-dasar Kewirausahaan Panduan Bagi Mahasiswa untuk Mengenal, Memahami, dan Memasuki Dunia Bisnis, Jakarta: Erlangga, 2011.
Herdiansyah, Haris. Metode Penelitian Kualitatif untuk Ilmu-Ilmu Sosial, Jakarta: Salemba Empat, 2012.

Johan, Suwinto. Studi Kelayakan Pengembangan Bisnis, Yogyakarta: Graha Ilmu, 2011. Kotler dan Amstrong. Dasardasar Pemasaran, Jakarta :Perhallindo, 2008.

, Dasar-dasar Pemasaran, Jakarta: Perhallindo, 2010.

Kotler, Philip dan Gary Amstrong. Dasar-dasar Pemasaran Principles of Marketing 7e, Jakarta: Prenhallindo, 1997.

Kotler, Philip dan Kevin Lane Keller. Manajemen Pemasaran, Jakarta: Prenhallindo, 2008.

Prasetyo, Bambang dan Lina Mifatahul Jannah. Metode Penelitian Kuantitatif : Teori dan Aplikasi, Jakarta :Raja Grafindo Persada, 2012.

Prawira, Bayu dan Ni Nyoman Kerti Yasa. Pengaruh Kualitas Produk, Citra Merek dan Persepsi Harga Terhadap Minat Beli Produk Smartphone Samsung dikota Denpasar ,Universitas Udayana, Bali, Indonesia

Suharyadi dan Purwanto. Statistika; untuk Ekonomi Keuangan Modern, Jakarta: Salemba Empat, 2007.

Sugiyono. Metode Penelitian Pendidikan :Pendekatan Kuantitatif, Kualitatif dan $R$ \& D, Bandung: Alfabeta, 2010.

Statistika untuk Penelitian, Bandung : Alfabeta, 2012.

Metode Penelitian Kuantitatif, Kualitatif dan $R \& D$, Bandung: Alfabeta, 2013.

Supranto dan Nandan Limakrisna. Perilaku Konsumen dan Strategi Pemasaran, Jakarta: Mitra Wacana Media, 2011. 
Swastha, Basu dan Irawan. Manajemen Pemasaran Modern, Yogyakarta: Liberty Offset, 2008.

Tjiptono, Fandy. Strategi Pemasaran, Yogyakarta: Andi Offset, 2008. Umar, Husein .Studi Kelayakan Bisnis, Edisi 2, Jakarta: Gramedia

Toko Usaha Muda Pasar Tanah Abang Zulkarnain. Ilmu Menjual, Yogyakarta: Graha Ilmu, 2012. 